\title{
Roseivivax halodurans gen. nov., sp. nov. and Roseivivax halotolerans sp. nov., aerobic bacteriochlorophyll-containing bacteria isolated from a saline lake
}

\author{
Tomonori Suzuki, Yasutaka Muroga, Manabu Takahama \\ and Yukimasa Nishimura
}

Department of Applied Biological Science, Science University of Tokyo, 2641, Yamazaki, Noda, Chiba 278-8510, Japan

\author{
Author for correspondence: Tomonori Suzuki. Tel: +8147124 1501. Fax: +81471239767. \\ e-mail: chijun@ rs.noda.sut.ac.jp
}

\begin{abstract}
Phenotypic and phylogenetic studies were performed with two strains (OCh $2^{239^{\top}}$ and $\mathrm{OCh} 210^{\top}, \mathrm{T}=$ type strain) of aerobic bacteriochlorophyll-containing bacteria isolated from the charophytes and the epiphytes on the stromatolites, respectively, of a saline lake located on the west coast of Australia. Both strains were chemoheterotrophic, Gram-negative and motile rods with subpolar flagella. Catalase and oxidase were produced. ONPG reaction was positive. Cells utilized D-glucose, acetate, butyrate, citrate, DL-lactate, DL-malate, pyruvate, succinate, L-aspartate and L-glutamate. Acids were produced from D-fructose and D-glucose. Bacteriochlorophyll a was synthesized under aerobic conditions. Strain OCh $239^{\top}$ had nitrate reductase and phosphatase. Acids were produced from L-arabinose, D-galactose, lactose, maltose, D-ribose and sucrose. The strain could grow in 0-20.0\% (w/v) NaCl. Strain OCh $210^{\top}$ had urease. Hydrolysis of gelatin was positive. Acids were produced from D-xylose. The strain could grow in $0.5-20.0 \%$ (w/v) NaCl. The results of 165 rRNA sequence comparisons revealed that strains $\mathrm{OCh}^{239^{\top}}$ and $\mathrm{OCh} 210^{\top}$ formed a new cluster within the $\alpha-3$ group of the $\alpha$ subclass of the class Proteobacteria. The similarity value of the 165 rRNA sequences between strains OCh $239^{\top}$ and OCh $210^{\top}$ was $95.8 \%$. Therefore, it was concluded that these two strains should be placed in a new genus, Roseivivax gen. nov., as the new species Roseivivax halodurans sp. nov. and Roseivivax halotolerans sp. nov. The type species of the genus is Roseivivax halodurans. The type strains of Roseivivax halodurans and Roseivivax halotolerans are OCh 239' ( = JCM 10272') and OCh $210^{\top}$ ( = JCM 10271T), respectively.
\end{abstract}

Keywords: Roseivivax halodurans, Roseivivax halotolerans, aerobic

bacteriochlorophyll-containing bacteria, saline lake, 16S rRNA

\section{INTRODUCTION}

The first paper on aerobic bacteriochlorophyllcontaining bacteria was published by Sato in 1978 . Afterwards, aerobic bacteriochlorophyll-containing bacteria were isolated from various sources (Shiba et al., 1979) and identified (Nishimura et al., 1981). Recently, new aerobic photosynthetic bacteria have been isolated from a hot spring (Hanada et al., 1997)

The GenBank/EMBL/DDBJ accession numbers for the 16S rRNA gene sequences of strains OCh $239^{\top}$ and OCh $210^{\top}$ are D85829 and D85831, respectively. and deep-ocean hydrothermal vents (Yurkov \& Beatty, 1998). Based on the phylogenetic analysis, it has been shown that these and newly isolated organisms belong to the $\alpha$ subclass of the class Proteobacteria. Acidiphilium (Wakao et al., 1993), Roseococcus (Yurkov et al., 1994), Craurococcus (Saito et al., 1998) and Paracraurococcus (Saito et al., 1998) are located in the $\alpha-1$ group. Methylobacterium (Green \& Bousfield, 1983) and Rhizobium sp. BTAi 1 (Evans et al., 1990) are located in the $\alpha-2$ group. Roseobacter (Shiba, 1991) is a member of the $\alpha-3$ group. Erythrobacter (Shiba \& Simidu, 1982), Erythromicrobium (Yurkov et al., 1994), Erythromonas (Yurkov et al., 


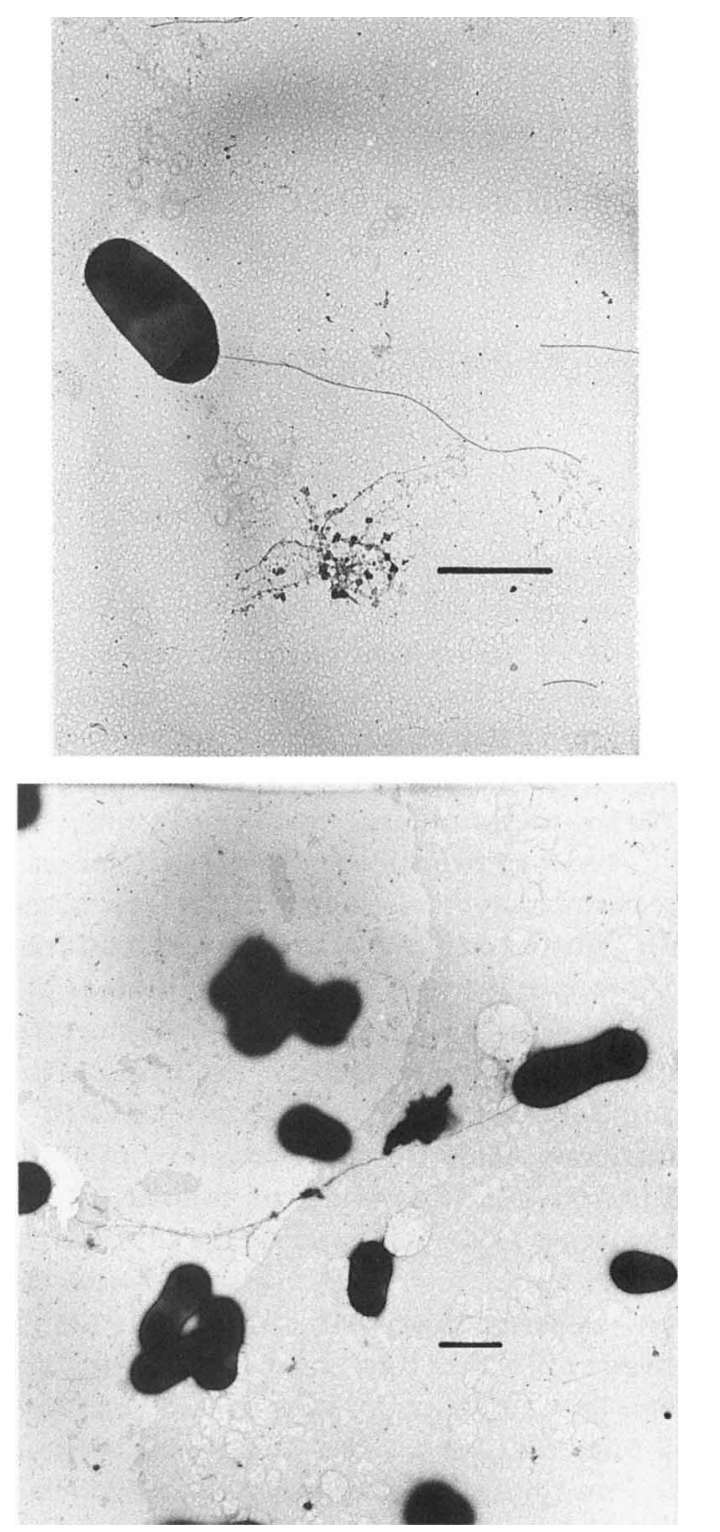

Fig. 1. Electron micrographs of negatively stained cells of strains OCh $239^{\top}$ (top) and OCh $210^{\top}$ (bottom). Bars, $1 \mu \mathrm{m}$.

1997), Porphyrobacter (Fuerst et al., 1993) and Sandaracinobacter (Yurkov et al., 1997) comprise the $\alpha-4$ group.

Shiba et al. (1991) isolated aerobic bacteriochlorophyll-containing bacteria from the east and west coasts of Australia. These organisms have been divided into four groups (Group I-IV) on the basis of colony colour, absorption spectrum type of bacteriochlorophyll and cell morphology (Nishimura et al., 1994). Based on the results of the DNA-DNA hybridization (Nishimura et al., 1994), each group (except Group III) has been divided into several genotype groups. Group II (19 strains) is divided into four genotype groups and the others (strains OCh 215, 231, 210, 239 and 263). In the present study, we investigated the phenotypic characteristics and the phylogenetic situation of strains OCh $239^{\mathrm{T}}(\mathrm{T}=$ type strain) and $\mathrm{OCh}$ $210^{\mathrm{T}}$ in Group II. Based on the results of this study, we propose the new genus Roseivivax with two new species, Roseivivax halodurans and Roseivivax halotolerans.

\section{METHODS}

Bacterial strains. Strains OCh $239^{\mathrm{T}}$ and OCh $210^{\mathrm{T}}$ were previously isolated from the charophytes and the epiphytes on the stromatolites, respectively, at Lake Clifton (isolated saline lake located in the west coast of Australia) by Shiba $e t$ al. (1991). The strains were cultivated on PPES-II medium (Taga, 1968) containing 2.0 g Bacto Peptone, $1.0 \mathrm{~g}$ Proteose Peptone No. 3, $1.0 \mathrm{~g}$ Bacto Soytone, $1.0 \mathrm{~g}$ Bacto Yeast extract, $0 \cdot 1 \mathrm{~g} \mathrm{Fe}(\mathrm{III})$-EDTA, $1000 \mathrm{ml}$ artificial sea water and $15.0 \mathrm{~g}$ agar (if needed). The artificial sea water contained (per litre) $30.0 \mathrm{~g} \mathrm{NaCl}, 0.7 \mathrm{~g} \mathrm{KCl}, 10.8 \mathrm{~g} \mathrm{MgCl}_{2} .6 \mathrm{H}_{2} \mathrm{O}, 5.4 \mathrm{~g}$ $\mathrm{MgSO}_{4} \cdot 7 \mathrm{H}_{2} \mathrm{O}$ and $1.0 \mathrm{~g} \mathrm{CaCl}_{2} .2 \mathrm{H}_{2} \mathrm{O}$. The $\mathrm{pH}$ was adjusted to 7.8 with $10 \%(\mathrm{w} / \mathrm{v}) \mathrm{NaOH}$. Roseobacter litoralis $\mathrm{OCh}$ $149^{\mathrm{T}}$ and Roseobacter denitrificans $\mathrm{OCh} 114^{\mathrm{T}}$ were used as references for physiological and biochemical characterization.

Electron microscopy. Cells were stained with $1 \%(\mathrm{w} / \mathrm{v})$ aqueous uranyl acetate and examined under a JEOL model JEM-1200 EX electron microscope at an accelerating voltage of $80 \mathrm{kV}$.

Physiological and biochemical characteristics. Physiological and biochemical characteristics were examined according to the methods of Shiba \& Simidu (1982).

Preparation of chromosomal DNA. Strains OCh $239^{\mathrm{T}}$ and OCh $210^{\mathrm{T}}$ were grown in PPES-II broth at $27^{\circ} \mathrm{C}$ with shaking. The cells were suspended in $0.1 \mathrm{M}$ saline EDTA $(0.15 \mathrm{M} \mathrm{NaCl}, 0.1 \mathrm{M}$ EDTA; $\mathrm{pH} 8.5)$, and then lysed at 60 ${ }^{\circ} \mathrm{C}$ for $10 \mathrm{~min}$ with $0.5 \%$ SDS as a final concentration. Chromosomal DNA was purified according to standard procedures (Sambrook et al., 1989).

Amplification of 16S rRNA gene. Amplification of $16 \mathrm{~S}$ rRNA gene was performed on a Quick Thermo Personal QTP-1 (Nippon Genetics) in $100 \mu \mathrm{l}$ reaction volume containing $100 \mathrm{ng}$ chromosomal DNA, $10 \mu \mathrm{l} 10 \times \mathrm{Ex}$ Taq buffer (Takara Shuzo), $200 \mu \mathrm{M}$ each dNTP, $1 \mu \mathrm{M}$ each primer and 2.5 U Takara Ex Taq (Takara Shuzo). The primers were 5' AGTTTGATCCTGGCTC 3' [Escherichia coli numbering system (Brosius et al., 1978): positions 10-25] and 5 AAGGAGGTGATCCAGCC 3' (positions 1525-1541). Amplification conditions were described previously (Suzuki \& Yamasato, 1994). The amplified DNA fragments were purified by gel electrophoresis on $1 \%$ Agarose S (Nippon Gene), and recovered with glass powder using the Prep-AGene DNA Purification System (Bio-Rad).

Sequencing and analysis of sequence data. Sequencing was carried out as described previously (Suzuki \& Yamasato, 1994). The sequences that were determined and the sequences of reference bacterial species were aligned using the program Clustal $\mathrm{W}$ version 1.7 (Thompson et al., 1994). The alignment was checked manually. Phylogenetic analysis was performed using the PHYLIP (phylogeny inference package) version $3.57 \mathrm{c}$ (Felsenstein, 1995). A distance matrix was calculated with DNADIST using the Kimura 2-parameter model, and a phylogenetic tree was reconstructed using NEIGHBOR. The stability of the clusters was ascertained by performing a bootstrap analysis (1000 replications) with DNABOOT, DNADIST, NEIGHBOR and CONSENSE. 


\section{RESULTS}

\section{Colony and cell morphology}

Colonies of strains OCh $239^{\mathrm{T}}$ and OCh $210^{\mathrm{T}}$ were circular, smooth, slightly convex, entire, glistening, opaque and pink. Electron micrographs of negatively stained cells showed that they were rods with subpolar flagella (Fig. 1). Cells of strain OCh $239^{\mathrm{T}}$ were $0.5-1.0 \times 1.0-5.0 \mu \mathrm{m}$, and cells of strain OCh $210^{\mathrm{T}}$ were $0.5-1.0 \times 1.0-3.0 \mu \mathrm{m}$.

\section{Physiological and biochemical characteristics}

Strains OCh $239^{\mathrm{T}}$ and OCh $210^{\mathrm{T}}$ grew chemoheterotrophically under aerobic conditions, but could not grow phototrophically under anaerobic conditions in the light. They synthesized bacteriochlorophyll $a$ under aerobic conditions. Optimum growth occurred at $\mathrm{pH} 7 \cdot 5-8.0$ and at $27-30^{\circ} \mathrm{C}$. The physiological and biochemical properties of strains OCh $239^{\mathrm{T}}$ and $\mathrm{OCh}$ $210^{\mathrm{T}}$ are shown in Table 1. These two strains had catalase and oxidase. Voges-Proskauer test was negative. ONPG reaction was positive. Both strains produced indole, but did not generate $\mathrm{H}_{2} \mathrm{~S}$. Starch, Tween 80 or alginate were not hydrolysed. Both strains utilized D-glucose, acetate, butyrate, citrate, DL-lactate, DL-malate, pyruvate, succinate, L-aspartate and
L-glutamate, but did not utilize fumarate, glycolate, ethanol or methanol. Acids were produced from Dfructose and D-glucose. Both strains were resistant to penicillin and tetracycline, but were sensitive to chloramphenicol and streptomycin.

Strain OCh $239^{\mathrm{T}}$ had nitrate reductase and phosphatase, but did not have urease. Gelatin was not hydrolysed. Acids were produced from L-arabinose, Dgalactose, lactose, maltose, D-ribose and sucrose, but were not produced from D-xylose. The strain could grow in media supplemented with $0-20.0 \%(\mathrm{w} / \mathrm{v})$ $\mathrm{NaCl}$.

Strain OCh $210^{\mathrm{T}}$ had urease, but did not have nitrate reductase or phosphatase. Gelatin was hydrolysed. Acids were produced from $\mathrm{D}$-xylose, but were not produced from $L$-arabinose, $D$-galactose, lactose, maltose, D-ribose or sucrose. The strain required $\mathrm{NaCl}$ for growth, and could grow in $0.5-20.0 \%(\mathrm{w} / \mathrm{v}) \mathrm{NaCl}$.

\section{Phylogenetic analysis}

The 16S rRNA gene sequences of strains OCh $239^{\mathrm{T}}$ and $\mathrm{OCh} 210^{\mathrm{T}}$ were determined, and aligned with the other available $16 \mathrm{~S}$ rRNA sequences of the strains that belong to the $\alpha-3$ group of the $\alpha$ subclass of the class Proteobacteria. A comparison of the 16S rRNA

Table 1. Differential characteristics of isolates and reference strains Roseobacter denitrificans OCh $114^{\top}$ and Roseobacter litoralis OCh $149^{\top}$

-, Negative; + , positive; w, weakly positive.

\begin{tabular}{|c|c|c|c|c|}
\hline Character & $\operatorname{Och} 239^{T}$ & $\operatorname{Och} 210^{T}$ & OCh114 ${ }^{\mathrm{T}}$ & OCh149 \\
\hline Nitrate reductase & + & - & + & - \\
\hline Phosphatase & + & - & + & - \\
\hline Urease & - & + & - & - \\
\hline \multicolumn{5}{|l|}{ Hydrolysis of: } \\
\hline Gelatin & - & + & + & + \\
\hline Tween 80 & - & - & + & + \\
\hline \multicolumn{5}{|l|}{ Utilization of: } \\
\hline Butyrate & + & + & - & + \\
\hline Fumarate & - & - & + & + \\
\hline Glycolate & - & - & + & + \\
\hline L-Aspartate & + & + & - & - \\
\hline \multicolumn{5}{|c|}{ Acid production from: } \\
\hline L-Arabinose & + & - & w & w \\
\hline D-Fructose & + & w & w & - \\
\hline D-Galactose & + & - & - & - \\
\hline D-Glucose & + & w & - & - \\
\hline Lactose & + & - & - & - \\
\hline Maltose & + & - & - & - \\
\hline D-Ribose & + & - & - & - \\
\hline Sucrose & + & - & - & - \\
\hline D-Xylose & - & w & - & w \\
\hline \multicolumn{5}{|c|}{ Growth in the presence of: } \\
\hline $0 \% \mathrm{NaCl}$ & w & - & - & - \\
\hline $20 \cdot 0 \% \mathrm{NaCl}$ & w & + & - & - \\
\hline
\end{tabular}




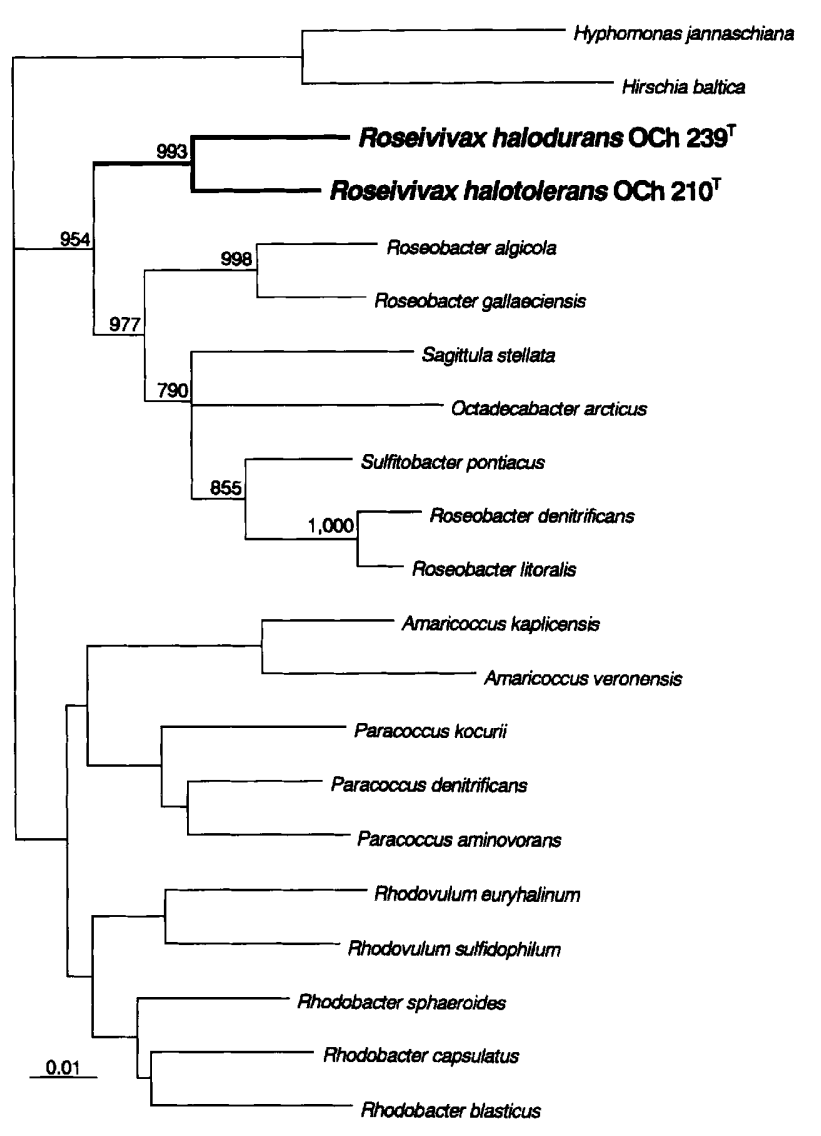

Fig. 2. Unrooted phylogenetic tree derived from the analysis of the 165 rRNA sequences of Roseivivax halodurans OCh $239^{\top}$, Roseivivax halotolerans OCh $210^{\top}$ and other members of the $\alpha$ subclass of the Proteobacteria. The numbers at the nodes indicate the levels of bootstrap support based on 1000 resamplings.

sequences revealed that strains OCh $239^{\mathrm{T}}$ and OCh $210^{T}$ belonged to the $\alpha-3$ group of the $\alpha$ subclass of the class Proteobacteria, forming a distinct cluster (Fig. 2). The cluster neighboured on Roseobacter algicola and Roseobacter gallaeciensis. The similarity values of the $16 \mathrm{~S}$ rRNA sequences of strains OCh $239^{\mathrm{T}}$ and $\mathrm{OCh}$ $210^{\mathrm{T}}$ to Roseobacter algicola and Roseobacter gallaeciensis were $91 \cdot 8-93 \cdot 3 \%$. The similarity value of the 16S rRNA sequences between strains OCh $239^{\mathrm{T}}$ and OCh $210^{\mathrm{T}}$ was $95 \cdot 8 \%$.

\section{DISCUSSION}

Aerobic bacteriochlorophyll-containing bacteria isolated from the east and west coasts of Australia (Shiba et al., 1991) have been divided into four groups on the basis of colony colour, absorption spectrum type of bacteriochlorophyll and cell morphology (Nishimura et al., 1994). These phenotypic groups have been investigated for their chemotaxonomic characteristics and by DNA-DNA hybridization. Strains OCh $239^{\mathrm{T}}$ and OCh $210^{\mathrm{T}}$ have been included in Group II, but did not belong to any of the genotype groups. To define the phylogenetic positions of these strains, we performed comparative $16 \mathrm{~S}$ rRNA sequence analysis. In consequence, it was revealed that strains OCh $239^{\mathrm{T}}$ and OCh $210^{\mathrm{T}}$ formed a new distinct cluster moderately related to Roseobacter algicola, Roseobacter gallaeciensis, Sagittula stellata, Octadecabacter arcticus and Sulfitobacter pontiacus. The cluster was distantly related to other taxa at the generic level (93.3\% 16S rRNA sequence similarity or less). The phylogenetic analysis supports the proposal of the new genus Roseivivax for strains OCh $239^{\mathrm{T}}$ and $\mathrm{OCh} 210^{\mathrm{T}}$.

Strain OCh $239^{\mathrm{T}}$ was phylogenetically distant from strain OCh $210^{\mathrm{T}}(95.8 \% 16 \mathrm{~S}$ rRNA sequence similarity). Phenotypic characteristics of strain OCh $239^{\mathrm{T}}$ were very different from those of strain OCh $210^{\mathrm{T}}$, i.e. nitrate reduction, urease, phosphatase, hydrolysis of gelatin and acid production from carbon sources. These results indicate that strains OCh $239^{T}$ and $\mathrm{OCh}$ $210^{\mathrm{T}}$ are different species.

In conclusion, we propose that strains $\mathrm{OCh} 239^{\mathrm{T}}$ and OCh $210^{\mathrm{T}}$ should be described as Roseivivax halodurans gen. nov., sp.nov. and Roseivivax halotolerans sp. nov., respectively.

\section{Description of Roseivivax gen. nov.}

Roseivivax (Ro.se.i.vi'vax. M.L. adj. roseus rosecoloured, pink; L. adj. vivax living; M.L. masc. n. Roseivivax pink living organism).

Cells are aerobic and Gram-negative rods that are motile by means of subpolar flagella. Catalase and oxidase are produced. Chemoheterotrophic. Bacteriochlorophyll $a$ is synthesized under aerobic conditions. The ubiquinone system is Q-10 (Nishimura et al., 1994). The major cellular fatty acids are C18:1 (Nishimura et al., 1994). The type species is Roseivivax halodurans.

\section{Description of Roseivivax halodurans sp. nov.}

Roseivivax halodurans (ha.lo.du'rans. Gr. n. hals salt; L. pres. part. durans enduring; M.L. part. adj. halodurans salt-enduring).

Colonies are circular, smooth, slightly convex, entire, glistening, opaque and pink. Cells are 0.5-1.0 $\times 1.0-5.0$ $\mu \mathrm{m}$. Optimum growth occurs at $\mathrm{pH} 7.5-8.0$ and at $27-30{ }^{\circ} \mathrm{C}$. Growth occurs in the presence of $0-20 \cdot 0 \%$ $(\mathrm{w} / \mathrm{v}) \mathrm{NaCl}$. Cells have nitrate reductase and phosphatase, but do not have urease. Voges-Proskauer test is negative. ONPG reaction is positive. Cells produce indole, but do not generate $\mathrm{H}_{2} \mathrm{~S}$. Hydrolysis of alginate, gelatin, starch and Tween 80 is negative. Cells utilize D-glucose, acetate, butyrate, citrate, DL-lactate, DL-malate, pyruvate, succinate, L-aspartate and Lglutamate, but do not utilize fumarate, glycolate, ethanol or methanol. Acids are produced from Larabinose, D-fructose, D-galactose, D-glucose, lactose, maltose, D-ribose and sucrose, but are not produced from D-xylose. Cells are resistant to penicillin and 
tetracycline, but are sensitive to chloramphenicol and streptomycin. The absorption spectrum of the membrane fraction in the near-IR region has maxima at 803 and $873 \mathrm{~nm}$ (Nishimura et al., 1994). The source of the strain is the charophytes of the saline lake. The $\mathrm{G}+\mathrm{C}$ content of the DNA is $64.4 \mathrm{~mol} \%$ (Nishimura et al., 1994). The type strain is strain OCh $239^{\mathrm{T}}(=\mathrm{JCM}$ $\left.10272^{\mathrm{T}}\right)$.

\section{Description of Roseivivax halotolerans sp. nov.}

Roseivivax halotolerans (ha.lo.to'le.rans. Gr. n. hals salt; L. pres. part. tolerans tolerating; M. L. part. adj. halotolerans salt-tolerating).

Colonies are circular, smooth, slightly convex, entire, glistening, opaque and pink. Cells are 0.5-1.0 $\times 1.0-5.0$ $\mu \mathrm{m}$. Optimum growth occurs at $\mathrm{pH} 7 \cdot 5-8.0$ and at $27-30^{\circ} \mathrm{C}$. Growth occurs in the presence of $0.5-20.0 \%$ $(\mathrm{w} / \mathrm{v}) \mathrm{NaCl}$. No growth occurs in the absence of $\mathrm{NaCl}$. Cells have urease, but do not have nitrate reductase or phosphatase. Voges-Proskauer test is negative. ONPG reaction is positive. Cells produce indole, but do not generate $\mathrm{H}_{2} \mathrm{~S}$. Hydrolysis of gelatin is positive, but hydrolysis of alginate, starch and Tween 80 is negative. Cells utilize D-glucose, acetate, butyrate, citrate, DLlactate, DL-malate, pyruvate, succinate, L-aspartate and L-glutamate, but do not utilize fumarate, glycolate, ethanol or methanol. Acids are produced from Dfructose, D-glucose and D-xylose, but are not produced from $\mathrm{L}$-arabinose, $\mathrm{D}$-galactose, lactose, maltose, $\mathrm{D}$ ribose or sucrose. Cells are resistant to penicillin and tetracycline, but are sensitive to chloramphenicol and streptomycin. The absorption spectrum of the membrane fraction in the near-IR region has maxima at 805 and $871 \mathrm{~nm}$ (Nishimura et al., 1994). The source of the strain is the epiphytes on the stromatolites of the saline lake. The $\mathrm{G}+\mathrm{C}$ content of the DNA is $59.7 \mathrm{~mol} \%$ (Nishimura et al., 1994). The type strain is strain OCh $210^{\mathrm{T}}\left(=\mathrm{JCM} 10271^{\mathrm{T}}\right)$.

\section{ACKNOWLEDGEMENTS}

We are grateful to Dr Tsuneo Shiba (National Fisheries University, Shimonoseki, Japan) for providing bacterial strains. We also thank Isamu Mutoh (Department of Applied Biological Science, Science University of Tokyo, Noda, Japan) for his help with electron microscopy.

\section{REFERENCES}

Brosius, J., Palmer, M. L., Kennedy, P. J. \& Noller, H. F. (1978). Complete nucleotide sequence of a $16 \mathrm{~S}$ ribosomal RNA gene from Escherichia coli. Proc Natl Acad Sci USA 75, 4801-4805.

Evans, W. R., Feischman, D. E., Calvert, H. E., Pyati, P. V., Alter, G. M. \& Rao, N. S. S. (1990). Bacteriochlorophyll and photosynthetic reaction centers in Rhizobium strain BTAi 1. Appl Environ Microbiol 56, 3445-3449.

Felsenstein, J. (1995). PHYLIP (phylogeny inference package), version 3.57c. Seattle: University of Washington.

Fuerst, J. A., Hawkins, J. A., Holmes, A., Sly, L. I., Moore, C. J. \& Stackebrandt, E. (1993). Porphyrobacter neustonensis gen. nov., sp. nov., an aerobic bacteriochlorophyll-synthesizing budding bacterium from fresh water. Int J Syst Bacteriol 43, 125-134.

Green, P. N. \& Bousfield, I. J. (1983). Emendation of Methylobacterium Patt, Cole, and Hanson 1976; Methylobacterium rhodinum (Heumann 1962) comb. nov. corrig.; and Methylobacterium radiotolerans (Ito and lizuka 1971) comb. nov. corrig.; and Methylobacterium mesophilicum (Austin and Goodfellow 1979) comb. nov. Int J Syst Bacteriol 33, 875-877.

Hanada, S., Kawase, Y., Hiraishi, A., Takaichi, S., Matsuura, K., Shimada, K. \& Nagashima, K. V. P. (1997). Porphyrobacter tepidarius sp. nov., a moderately thermophilic aerobic photosynthetic bacterium isolated from a hot spring. Int $J$ Syst Bacteriol 47, 408-413.

Nishimura, Y., Shimadzu, M. \& lizuka, H. (1981). Bacteriochlorophyll formation in radiation-resistant Pseudomonas radiora. J Gen Appl Microbiol 27, 427-430.

Nishimura, Y., Muroga, Y., Saito, S., Shiba, T., Takamiya, K. \& Shioi, Y. (1994). DNA relatedness and chemotaxonomic feature of aerobic bacteriochlorophyll-containing bacteria isolated from coasts of Australia. J Gen Appl Microbiol 40, 287-296.

Saito, S., Suzuki, T. \& Nishimura, Y. (1998). Proposal of Craurococcus roseus gen. nov., sp. nov. and Paracraurococcus ruber sp. nov., novel aerobic bacteriochlorophyll $a$-containing bacteria from soil. Int J Syst Bacteriol 48, 1043-1047.

Sambrook, J., Fritsch, E. F. \& Maniatis, T. (1989). Molecular Cloning: a Laboratory Manual, 2nd edn. Cold Spring Harbor, NY: Cold Spring Harbor Laboratory.

Sato, K. (1978). Bacteriochlorophyll formation by facultative methylotrophs, Protaminobacter ruber and Pseudomonas AM1. FEBS Lett 85, 207-210.

Shiba, T. (1991). Roseobacter litoralis gen. nov., sp. nov. and Roseobacter denitrificans sp. nov., aerobic pink-pigmented bacteria which contain bacteriochlorophyll a. Syst Appl Microbiol 14, 140-145.

Shiba, T. \& Simidu, U. (1982). Erythrobacter longus gen. nov., sp. nov., an aerobic bacterium which contains bacteriochlorophyll a. Int J Syst Bacteriol 32, 211-217.

Shiba, T., Simidu, U. \& Taga, N. (1979). Distribution of aerobic bacteria which contain bacteriochlorophyll a. Appl Environ Microbiol 38, 43-45.

Shiba, T., Shioi, Y., Takamiya, K., Sutton, D. C. \& Wilkinson, C. R. (1991). Distribution and physiology of aerobic bacteria containing bacteriochlorophyll $a$ on the east and west coasts of Australia. Appl Environ Microbiol 57, 295-300.

Suzuki, T. \& Yamasato, K. (1994). Phylogeny of spore-forming lactic acid bacteria based on $16 \mathrm{~S}$ rRNA gene sequences. FEMS Microbiol Lett 115, 13-18.

Taga, N. (1968). Some ecological aspects of marine bacteria in the kuroshio current. Bull Misaki Mar Biol Inst Kyoto Univ 12, 56-76.

Thompson, J. D., Higgins, D. G. \& Gibson, T. J. (1994). CLUSTAL $\mathrm{W}$ : improving the sensitivity of progressive multiple sequence alignment through sequence weighting, positions-specific gap penalties and weight matrix choice. Nucleic Acids Res 22 , 4673-4680.

Wakao, N., Shiba, T., Hiraishi, A., Ito, M. \& Sakurai, Y. (1993). Distribution of bacteriochlorophyll a in species of the genus Acidiphilium. Curr Microbiol 27, 277-279.

Yurkov, V. \& Beatty, J. T. (1998). Isolation of aerobic anoxygenic photosynthetic bacteria from black smoker plume waters of the Juan de Fuca Ridge in the Pacific Ocean. Appl Environ Microbiol 64, 337-341. 
Yurkov, V., Stackebrandt, E., Holmes, A. \& 7 other authors (1994). Phylogenetic positions of novel aerobic, bacteriochlorophyll $a$ containing bacteria and description of Roseococcus thiosulfatophilus gen. nov., sp. nov., Erythromicrobium ramosum gen. nov., sp. nov., and Erythrobacter litoralis sp. nov. Int J Syst Bacteriol 44, 427-434.
Yurkov, V., Stackebrandt, E., Buss, O., Vermeglio, A., Gorlenko, V. \& Beatty, J. T. (1997). Reorganization of the genus Erythromicrobium: description of "Erythromicrobium sibiricum" as Sandaracinobacter sibiricus gen. nov., sp. nov., and of " Erythromicrobium ursincola" as Erythromonas ursincola gen. nov., sp. nov. Int J Syst Bacteriol 47, 1172-1178. 